\title{
Hoeflea alexandrii sp. nov., isolated from the toxic dinoflagellate Alexandrium minutum AL1V
}

Correspondence

Irma Marín

imarin@cbm.uam.es

\author{
Lucía Palacios, ${ }^{1}$ David R. Arahal, ${ }^{2}$ Beatriz Reguera ${ }^{3}$ and Irma Marín ${ }^{1}$ \\ 'Centro de Biología Molecular 'Severo Ochoa', Universidad Autónoma de Madrid, Cantoblanco, \\ 28049 Madrid, Spain \\ ${ }^{2}$ Colección Española de Cultivos Tipo (CECT) and Departamento de Microbiología y Ecología, \\ Universitat de València, 46100 Burjassot, València, Spain \\ ${ }^{3}$ Instituto Español de Oceanografía, Centro Oceanográfico de Vigo, PO Box 1552, 36200 \\ Vigo, Pontevedra, Spain
}

A Gram-negative, aerobic, non-symbiotic bacterium $\left(\mathrm{AM} 1 \mathrm{~V} 30^{\top}\right)$ was isolated from the toxic dinoflagellate Alexandrium minutum AL1V. On the basis of $16 \mathrm{~S}$ rRNA gene sequence similarity, strain $\mathrm{AM} 1 \mathrm{~V} 30^{\top}$ was most closely related ( $97 \cdot 4 \%$ similarity) to the type strain of Hoeflea marina, which belongs to the family Phyllobacteriaceae within the order Rhizobiales of the class Alphaproteobacteria. A polyphasic approach was used to clarify the taxonomic position of strain $\mathrm{AM} 1 \mathrm{~V} \mathrm{O}^{\top}$. During the course of this study, a second species was described by others as belonging to the genus Hoeflea, namely Hoeflea phototrophica; it showed a somewhat higher level of

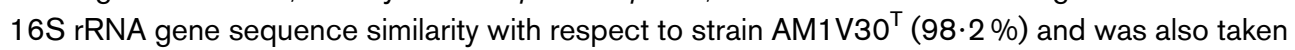
into account. The fatty acid profiles, physiological and biochemical data and DNA G+C content $(59.7 \mathrm{~mol} \%)$ support the classification of strain $\mathrm{AM} 1 \mathrm{~V} 3 \mathrm{O}^{\top}$ as a member of the genus Hoeflea. The characteristics of the novel strain were sufficiently distinct to indicate that it represents a separate species. To confirm this conclusion, DNA-DNA hybridizations were performed: low values (between 15.8 and $29.8 \%$ ) were obtained in all cases. Thus, $\mathrm{AM}^{\mathrm{V}} \mathrm{V} 30^{\top}$ represents a novel species within the genus Hoeflea, for which the name Hoeflea alexandrii sp. nov. is proposed. Strain AM1V30 ${ }^{\top}\left(=\right.$ CECT $5682^{\top}=$ DSM $\left.16655^{\top}\right)$ is the type strain.
The Taxonomic Outline of the Prokaryotes (Garrity et al., 2004) indicates that the family Phyllobacteriaceae consists of eight genera representing various origins and lifestyles: Phyllobacterium (Knösel, 1984), Aminobacter (Urakami et al., 1992), Aquamicrobium (Bambauer et al., 1998), Defluvibacter (Fritsche et al., 1999), 'Candidatus Liberobacter' (Jagoueix et al., 1994), Mesorhizobium (Jarvis et al., 1997), Nitratireductor (Labbé et al., 2004) and Pseudaminobacter (Kämpfer et al., 1999). Two other genera, Parvibaculum (Schleheck et al., 2004) and Hoeflea (Peix et al., 2005), have since been proposed for consideration as members of this family, on the basis of 16S rRNA gene sequence data. The genus Hoeflea was created to accommodate a single species, Hoeflea marina, based on a strain of marine origin (from the Baltic Sea, off the coast of Germany) previously assigned to the species Agrobacterium ferrugineum (Peix et al., 2005). More recently, a second species within this genus was proposed, Hoeflea phototrophica (Biebl

The GenBank/EMBL/DDBJ accession number for the 16S rRNA gene sequence of strain $\mathrm{AM} 1 \mathrm{~V} 30^{\top}$ is $\mathrm{AJ} 786600$.

Transmission electron micrographs of strain $\mathrm{AM} \mathrm{V} 30^{\top}$ are available as a supplementary figure in IJSEM Online. et al., 2006), for isolates from cultures of marine dinoflagellates (three strains from Alexandrium lusitanicum and two from Prorocentrum lima). This study deals with the characterization of a novel isolate, strain $\mathrm{AM} 1 \mathrm{~V} 30^{\mathrm{T}}$, and the proposal of a novel species of the genus Hoeflea.

Strain $\mathrm{AM} 1 \mathrm{~V} 30^{\mathrm{T}}$ was isolated from a culture of the toxinproducing marine dinoflagellate Alexandrium minutum AL1V (Instituto Español de Oceanografia, Vigo, Spain). Alexandrium minutum is a planktonic species associated with shellfish poisoning events (toxic, paralytic) in coastal regions around the world (Lilly et al., 2005). The specific relationship between bacteria and dinoflagellates is not well understood, but some authors consider that some of them might be symbiotic, as bacteria have been detected inside dinoflagellate cells (Cavanaugh, 1994; Lewis et al., 2001). Strain $\mathrm{AM} 1 \mathrm{~V} 30^{\mathrm{T}}$ is able to grow axenically in vitro and it also yields blooms in cultures of the microalga from which it was isolated and of another closely related clone (AL4V).

For isolation of bacteria, samples of the harvested dinoflagellate culture were taken under sterile conditions, washed in $1 \times$ PBS and then collected again by centrifugation. Cells were sonicated (Branson 2200E-1; Branson Ultrasonic) for 
5 min with $1 \mathrm{~min}$ intervals on ice. Aliquots of the sonicated dinoflagellate cell suspension were streaked on full- and half-strength marine agar 2216 (Difco) for 7 days at $15^{\circ} \mathrm{C}$. Only one type of colony - circular and pigmented light brown - was obtained. For maintenance and further testing, cells were incubated in marine agar or marine broth 2216 (Difco) at $30^{\circ} \mathrm{C}$ unless stated otherwise.

Cell morphology of cultures (after 3-4 days incubation) was observed under a Zeiss Axioskop light microscope; phasecontrast observations were included. The size and ultrastructure of the cells were determined by transmission electron microscopy (see Supplementary Fig. S1 available in IJSEM Online). Cells were negatively stained with uranyl acetate $(2 \% \mathrm{w} / \mathrm{v}, \mathrm{pH} 4.5)$ and were observed with a JEOL1010 microscope (Centro de Biología Molecular, Universidad Autónoma de Madrid, Madrid, Spain): monotrichous polar flagellation was observed (Supplementary Fig. S1).

Growth was assessed at $4,10,20,30,37,42$ and $50{ }^{\circ} \mathrm{C}$ and at $\mathrm{pH} 5,6,7,8,9$ and 10 . To assess the salinity requirements/ tolerance of strain $\mathrm{AM} 1 \mathrm{~V} 30^{\mathrm{T}}, 0,0 \cdot 8,1 \cdot 5,3,6$ and $10 \% \mathrm{NaCl}$ or 2.5 and $5 \%$ sea salts (Sigma) were added to salt-free ZoBell medium, half-strength ZoBell medium and fullstrength ZoBell medium (Oppenheimer \& ZoBell, 1952). In all cases, both broth and solid media were tested. For comparison purposes, strain $\mathrm{AM} 1 \mathrm{~V} 30^{\mathrm{T}}$ was also inoculated into basal medium agar consisting of $0.3 \%$ yeast extract (Difco), 1\% Bacto-peptone (Becton Dickinson), 0.5\% $\mathrm{NaCl}$ (Merck) and $1.5 \%$ agar (Pronadisa). The optimal temperature for growth was $30^{\circ} \mathrm{C}$. Strain $\mathrm{AM} 1 \mathrm{~V} 30^{\mathrm{T}}$ was unable to grow at 4 or $50^{\circ} \mathrm{C}$. This micro-organism required $\mathrm{pH}$ values within the range $6-9$, optimal growth occurring at $\mathrm{pH}$ 7. Regarding salinity, growth was supported at 0 (salt-free ZoBell medium without added salts) to $11 \cdot 8 \%$ total salts (half-strength ZoBell medium plus $10 \% \mathrm{NaCl}$ ). Optimal growth occurred at $0-6 \cdot 8 \%$ total salts, indicating that strain $\mathrm{AM} 1 \mathrm{~V} 30^{\mathrm{T}}$ must be considered as a marine organism that exhibits moderate halotolerance. No significant difference in the growth rate was observed with media employing only $\mathrm{NaCl}$ instead of sea salts (or sea salts plus $\mathrm{NaCl}$ ). This, together with the fact that salt-free media supported growth, shows that, despite its marine origin, strain AM1V $30^{\mathrm{T}}$ does not have any specific ionic requirement.

The isolate was tested by using standard procedures (Gerhardt et al., 1994) and using the whole test spectrum of the bioMérieux API 20NE kit (for biochemical reactions) and the API ZYM kit (for extracellular enzyme activities). Strips were incubated at $30^{\circ} \mathrm{C}$ for $24 \mathrm{~h}$ (API ZYM) or $48 \mathrm{~h}$ (API 20NE). Carbohydrate metabolism was investigated using API $50 \mathrm{CH}$ strips (bioMérieux) in conjunction with API $50 \mathrm{CHB} / \mathrm{E}$ medium and according to the instructions of the manufacturer. API $50 \mathrm{CH}$ strips were read after incubation for 24 and $48 \mathrm{~h}$ at $30^{\circ} \mathrm{C}$.

The response of strain $\mathrm{AM} 1 \mathrm{~V} 30^{\mathrm{T}}$ to different antibiotics was tested by using filter-paper discs (Mast Diagnostics) containing antibiotics at the following concentrations: ampicillin, $25 \mu \mathrm{g}$; cephalothin, $30 \mu \mathrm{g}$; chloramphenicol, $30 \mu \mathrm{g}$; erythromycin, $15 \mu \mathrm{g}$; nalidixic acid, $30 \mu \mathrm{g}$; streptomycin, $15 \mu \mathrm{g}$; tetracycline, $30 \mu \mathrm{g}$; and trimethoprim, $5 \mu \mathrm{g}$. The isolate was resistant to ampicillin, nalidixic acid and trimethoprim and sensitive to streptomycin, tetracycline, cephalothin, erythromycin and chloramphenicol.

Genomic DNA was extracted from bacterial cells and purified using the Fast DNA kit (Qbiogene). The 16S rRNA gene was amplified by a PCR using the primers $27 \mathrm{f}\left[5^{\prime}-\right.$ AGAGTTTGATC(C/A)TGGCTCAG-3'] and 1492r [5'-TACGG(C/T)TACCTTGTTACGACTT-3'] (Lane, 1991). PCR amplification of the 16S rRNA gene was done as described by Orphan et al. (2001) and the products were sequenced directly as described by Moore et al. (1999). The Taq dideoxy terminator cycle sequencing kit (Perkin Elmer Applied Biosystems) was used to sequence the 16S rRNA gene. The reactions were run on an Applied Biosystems $373 \mathrm{~S}$ DNA sequencer.

Sequences were compared with public sequences in the EMBL gene sequence databases by using the BLAST program (National Center for Biotechnology Information; http:// ncbi.nlm.nih.gov/). Related sequences were further analysed using the program package ARB (Ludwig et al., 2004; http:// www.arb-home.de). Sequence alignments were corrected manually using the sequence editor ARB_EDIT. Phylogenetic analysis using alternative treeing methods (maximum parsimony, maximum likelihood and distance matrix) and data subsets was performed using the appropriate ARB tools (Ludwig et al., 1998). Fig. 1 shows the tree derived by analysis with Jukes-Cantor corrections. Phylogenetic analysis revealed that strain $\mathrm{AM} 1 \mathrm{~V} 30^{\mathrm{T}}$ is a member of the family Phyllobacteriaceae, its closest relatives being $H$. phototrophica and $H$. marina $(98 \cdot 2$ and $97 \cdot 4 \%$ sequence similarity to the respective type strains). Levels of similarity to sequences from species of neighbouring genera were significantly lower: Mesorhizobium, 96.2-96.8 \%; Phyllobacterium, 94.496.2\%; Aminobacter, 95.9-96.1\%; Pseudaminobacter, 95.4-96.0\%; Nitratireductor, 95.8\%; Defluvibacter, $95 \cdot 7 \%$; and Aquamicrobium, $95 \cdot 6 \%$. Moreover, the sequence of strain $\mathrm{AM} 1 \mathrm{~V} 30^{\mathrm{T}}$ consistently aligned with those of the two Hoeflea species, regardless of the treeing method, which means that it can be considered as a member of the same genus.

The DNA G + C content (mol\%) was determined by HPLC at the Deutsche Sammlung von Mikroorganismen und Zellkulturen (DSMZ; Braunschweig, Germany) according to the procedure of Mesbah et al. (1989). Strain AM1V30 has a DNA G $+\mathrm{C}$ content of $59 \cdot 7 \mathrm{~mol} \%$, which is $6.6 \mathrm{~mol} \%$ higher than that of H. marina LMG $128^{\mathrm{T}}(53 \cdot 1 \mathrm{~mol} \%)$ (Peix et al., 2005) but almost identical to that of H. phototrophica DFL-43 ${ }^{\mathrm{T}}(59 \cdot 3 \mathrm{~mol} \%)$ (Biebl et al., 2006).

The cellular fatty acid composition of strain $\mathrm{AM} 1 \mathrm{~V} 30^{\mathrm{T}}$ was analysed by GLC at the DSMZ, using a method described previously (Kämpfer \& Kroppenstedt, 1996). The profile obtained largely resembled those of the two Hoeflea species, 


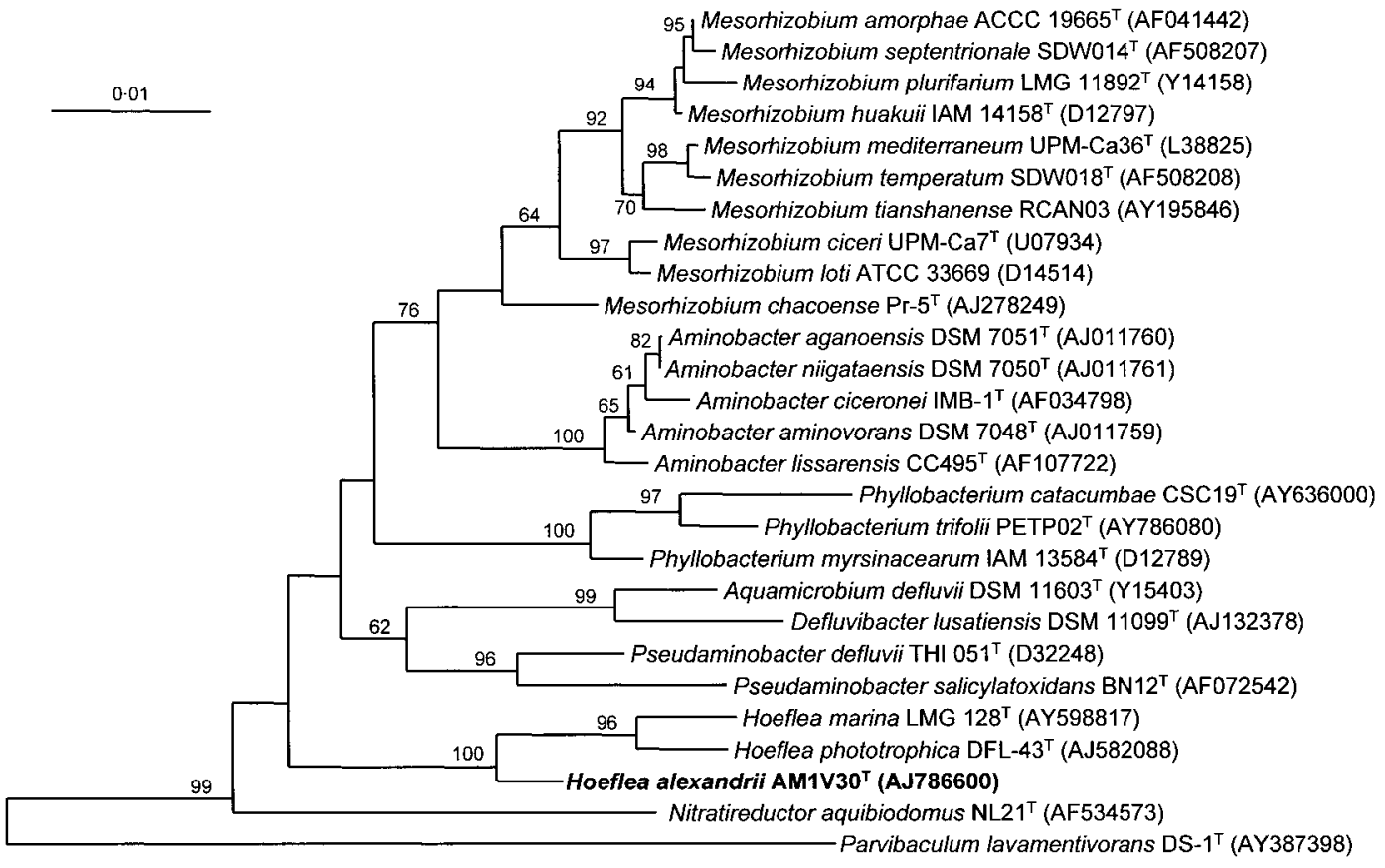

Fig. 1. Neighbour-joining phylogenetic tree based on almost-complete $16 \mathrm{~S}$ rRNA gene sequences of $\operatorname{strain} \mathrm{AM}_{1 \mathrm{~V}} 30^{\top}$ and members of the family Phyllobacteriaceae. Bootstrap values (percentages of 1000 resamplings) greater than $60 \%$ are shown at branching points. Sequence accession numbers are given in parentheses. Bar, 1 estimated substitution per 100 base positions.

except with regard to the relative amounts and the presence or absence of some fatty acids in one of the three organisms (Table 1).

The production of bacteriochlorophyll $a$ by strain AM1V $30^{\mathrm{T}}$ was investigated as described by Biebl et al. (2006) for $H$. phototrophica: the absorption spectrum lacked the peaks of bacteriochlorophyll $a$ and a carotenoid that are found in H. phototrophica. Thus, in this respect, strain AM1V30 resembles $H$. marina.

As has been indicated above, strain $\mathrm{AM} 1 \mathrm{~V} 30^{\mathrm{T}}$ belongs to the genus Hoeflea on the basis of 16S rRNA gene sequence data. The values for sequence similarity with respect to the type strains of the two species of the genus, $H$. phototrophica and $H$. marina (98.2 and $97 \cdot 4 \%$, respectively), are above the limit suggested by Stackebrandt \& Goebel (1994) as defining bacterial species. However, given the number of phenotypic traits that differentiate strain $\mathrm{AM} 1 \mathrm{~V} 30^{\mathrm{T}}$ and those species (see Table 2 and comments above), DNA-DNA hybridization was deemed necessary to confirm its status as a separate species.

Whole-genome hybridization assays were performed at the DSMZ. DNA was isolated using a French pressure cell (Thermo Spectronic) and was purified by chromatography on hydroxyapatite as described by Cashion et al. (1977). DNA-DNA hybridization was carried out as described by De Ley et al. (1970), with the modifications of Huß
Table 1. Fatty acid methyl ester profiles of strain $A M 1 V 30^{\top}$ and related type strains

Strains: $1, \operatorname{AM} 1 \mathrm{~V} 30^{\mathrm{T}}$ (data from this study); 2, H. marina LMG $128^{\mathrm{T}}$ (Peix et al., 2005); 3, H. phototrophica DFL-43 ${ }^{\mathrm{T}}$ (Biebl et al., 2006). Values are mean percentages of total fatty acid methyl esters. tr, Trace amount $(\leqslant 1 \cdot 0 \%)$; ND, not detected.

\begin{tabular}{|lccr|}
\hline Fatty acid & $\mathbf{1}$ & $\mathbf{2}$ & $\mathbf{3}$ \\
\hline Saturated fatty acids & & & \\
$14: 0$ & $\operatorname{tr}$ & $\mathrm{ND}$ & $\mathrm{ND}$ \\
$16: 0$ & $7 \cdot 7$ & $4 \cdot 0$ & $6 \cdot 3$ \\
$18: 0$ & $1 \cdot 4$ & $1 \cdot 4$ & $1 \cdot 2$ \\
Unsaturated fatty acids & & & \\
$16: 1 \omega 11 c$ & $\operatorname{tr}$ & $\mathrm{ND}$ & $\mathrm{ND}$ \\
$17: 1 \omega 8 c$ & $\mathrm{ND}$ & $\operatorname{tr}$ & $\mathrm{ND}$ \\
$18: 1 \omega 7 c$ & $83 \cdot 1$ & $76 \cdot 0$ & $62 \cdot 8$ \\
$18: 1 \omega 9 c$ & $\operatorname{tr}$ & $\mathrm{ND}$ & $\mathrm{ND}$ \\
$20: 1 \omega 9 t$ & $\mathrm{ND}$ & $\operatorname{tr}$ & $\mathrm{ND}$ \\
$11-$ Methyl $18: 1 \omega 7 c$ & $3 \cdot 6$ & $7 \cdot 5$ & $20 \cdot 6$ \\
Cyclopropane acids & & & \\
$19: 0$ cyclo $\omega 8 c$ & $\mathrm{ND}$ & $5 \cdot 6$ & $1 \cdot 6$ \\
$19: 1$ cyclo & $\mathrm{ND}$ & $\mathrm{ND}$ & $3 \cdot 4$ \\
Summed features & & & \\
$14: 03-\mathrm{OH}$ and/or $16: 1$ iso I & $\operatorname{tr}$ & $\mathrm{ND}$ & $\mathrm{ND}$ \\
$16: 1 \omega 7 c$ and/or $15: 0$ iso $2-\mathrm{OH}$ & $2 \cdot 3$ & $2 \cdot 6$ & $1 \cdot 6$ \\
Unknown & $\mathrm{ND}$ & $\operatorname{tr}$ & $2 \cdot 4$ \\
& & & \\
\hline
\end{tabular}


Table 2. Differentiating characteristics for the novel strain and species of the genus Hoeflea

Strains: 1, $\operatorname{AM} 1 \mathrm{~V} 30^{\mathrm{T}}$ (data from this study); 2, H. marina LMG $128^{\mathrm{T}}$ (Peix et al., 2005); 3, H. phototrophica DFL- $43^{\mathrm{T}}$ (Biebl et al., 2006). ND, Not detected; W, weak reaction.

\begin{tabular}{|lccc|}
\hline Characteristic & $\mathbf{1}$ & $\mathbf{2}$ & $\mathbf{3}$ \\
\hline Colony pigmentation & Light & White-cream None/beige \\
& brown & \multicolumn{2}{c|}{} \\
Bacteriochlorophyll $a$ & - & - & + \\
Optimal salinity $(\% \mathrm{NaCl})$ & $0-6 \cdot 8$ & 3 & $\mathrm{ND}$ \\
Salinity range $(\% \mathrm{NaCl})$ & $0-11 \cdot 8$ & $0-5$ & $0 \cdot 5-7$ \\
Temperature range $\left({ }^{\circ} \mathrm{C}\right)$ & $10-42$ & $4-37$ & $15-33$ \\
Urease activity & - & + & $\mathrm{ND}$ \\
Hydrolysis of gelatin & - & W & - \\
Assimilation of: & & & \\
D-Glucose & - & + & $\mathrm{W}$ \\
L-Arabinose & - & + & $\mathrm{ND}$ \\
D-Mannose & - & + & $\mathrm{ND}$ \\
D-Mannitol & - & + & $\mathrm{ND}$ \\
D-Maltose & - & + & $\mathrm{ND}$ \\
Malate & - & + & + \\
Gentiobiose & + & - & $\mathrm{ND}$ \\
DNA G+C content $(\mathrm{mol} \%)$ & $59 \cdot 7$ & $53 \cdot 1$ & $59 \cdot 3$ \\
& & & \\
\hline
\end{tabular}

et al. (1983), using a Cary 100 Bio UV/VIS spectrophotometer equipped with a Peltier-thermostatted $6 \times 6$ multicell changer and a temperature controller with an in situ temperature probe (Varian). Experiments were run in duplicate, giving the following results: strain AM1V30 ${ }^{\mathrm{T}}$ against $H$. marina DSM $16791^{\mathrm{T}}, 15 \cdot 8$ and $17 \cdot 2 \%$; strain $\mathrm{AM}_{\mathrm{V}} 30^{\mathrm{T}}$ against $H$. phototrophica DSM $17068^{\mathrm{T}}, 29 \cdot 8$ and $21 \cdot 3 \%$. The low values obtained support the definitive conclusion that strain $\mathrm{AM} 1 \mathrm{~V} 30^{\mathrm{T}}$ represents a novel species within the genus Hoeflea, for which the name Hoeflea alexandrii sp. nov. is proposed.

\section{Description of Hoeflea alexandrii sp. nov.}

Hoeflea alexandrii (a.lex.an'dri.i. N.L. gen. n. alexandrii of Alexandrium, the genus name of the dinoflagellate Alexandrium minutum, the source of isolation of the type strain).

Cells are Gram-negative, non-spore-forming rods, about $2.5 \times 0.8 \mu \mathrm{m}$ in size and motile by single polar flagella. Colonies on marine agar 2216 are circular, around 1-2 mm in diameter and pigmented light brown after 2 days incubation at $30^{\circ} \mathrm{C}$. Optimal growth occurs at $30^{\circ} \mathrm{C}$ and $\mathrm{pH}$ 7. The temperature and $\mathrm{pH}$ ranges for growth are $10-42{ }^{\circ} \mathrm{C}$ and $\mathrm{pH} 6-9$, respectively. Shows no specific ionic requirement, growing with salts in the range $0-11 \cdot 8 \%$ (optimally between 0 and $6 \cdot 8 \%$ ). Oxidase-negative and catalase-positive. Does not reduce nitrate to nitrite or nitrogen. The following API 20NE tests give positive results: hydrolysis of aesculin and $\beta$-galactosidase activity (PNPG).
The following API 20NE tests give negative results: nitrate reduction, indole production, acids from glucose, arginine dihydrolase, urease, hydrolysis of gelatin and assimilation of D-glucose, L-arabinose, D-mannose, D-mannitol, $\mathrm{N}$ acetylglucosamine, D-maltose, gluconate, caproate, adipate, malate, citrate and phenylacetate. Positive for the following enzyme activities (API ZYM): alkaline phosphatase, esterase (C4), esterase lipase (C8), leucine arylamidase, valine arylamidase, cystine arylamidase, naphthol-AS-BIphosphohydrolase, $\alpha$-glucosidase and $\beta$-glucosidase. Negative for the following enzyme activities (API ZYM): lipase (C14), trypsin, $\alpha$-chymotrypsin, acid phosphatase, $\alpha$ galactosidase, $\beta$-galactosidase, $\beta$-glucuronidase, $N$-acetyl$\beta$-glucosaminidase, $\alpha$-mannosidase and $\alpha$-fucosidase. Ferments the following substrates (API $50 \mathrm{CH}$ ): glycerol, L-arabinose, D-ribose, D-xylose, D-glucose, D-fructose, Dmannose, inositol, D-mannitol, D-sorbitol, methyl $\alpha$-Dglucopyranoside, amygdalin, arbutin, aesculin, salicin, D-cellobiose, D-maltose, sucrose, D-trehalose, inulin, Draffinose, starch, glycogen, gentiobiose, D-turanose, D-lyxose, D-fucose, L-fucose, potassium gluconate and potassium 2-ketogluconate. Does not ferment erythritol, $\mathrm{D}$-arabinose, L-xylose, D-adonitol, methyl $\beta$-D-xylopyranoside, D-galactose, L-sorbose, L-rhamnose, dulcitol, methyl $\alpha$-D-mannopyranoside, $N$-acetylglucosamine, D-lactose, Dmelibiose, D-melezitose, xylitol, D-tagatose, D-arabitol, Larabitol or potassium 5-ketogluconate. Growth on artificial seawater with phosphate and traces of minerals and vitamins, supplemented with glycerol or glucose as sole carbon source, is weak. Organic acids do not support growth. Resistant to ampicillin $(25 \mu \mathrm{g})$, nalidixic acid $(30 \mu \mathrm{g})$ and trimethoprim $(5 \mu \mathrm{g})$; sensitive to cephalothin $(30 \mu \mathrm{g})$, chloramphenicol $(30 \mu \mathrm{g})$, erythromycin $(15 \mu \mathrm{g})$, streptomycin $(15 \mu \mathrm{g})$ and tetracycline $(30 \mu \mathrm{g})$. Fatty acids detected in strain $\mathrm{AM} 1 \mathrm{~V} 30^{\mathrm{T}}$ include (in order of abundance): $18: 1 \omega 7 c \quad(83 \cdot 1 \%), \quad 16: 0 \quad(7 \cdot 7 \%), \quad 11$-methyl $18: 1 \omega 7 c(3.6 \%)$, summed feature $3(16: 1 \omega 7 c$ and/or $15: 0$ iso $2-\mathrm{OH} ; 2 \cdot 3 \%), 18: 0(1 \cdot 4 \%)$ and minor amounts of other fatty acids. The DNA G $+\mathrm{C}$ content of the type strain is $59 \cdot 7 \mathrm{~mol} \%$.

The type strain, $\operatorname{AM} 1 \mathrm{~V} 30^{\mathrm{T}}\left(=\mathrm{CECT} 5682^{\mathrm{T}}=\mathrm{DSM} 16655^{\mathrm{T}}\right)$, was isolated from a culture of the toxin-producing marine dinoflagellate Alexandrium minutum AL1V (Instituto Español de Oceanografia, Vigo, Spain).

\section{Acknowledgements}

We are most grateful to Professor Dr Hans G. Trüper for his assistance with the Latin nomenclature. Thanks are due to Dr S. Fraga for providing the Alexandrium minutum strain used in this work, and to A. Fernández for technical assistance. L. P. was funded by a fellowship from the Comunidad de Madrid. This work was supported by grant CTM2004-04078.C03-03/MAR from the Spanish Ministerio de Ciencia y Tecnología (to I. M.) and an institutional grant to the Centro de Biología Molecular 'Severo Ochoa' from Fundación Ramón Areces. D.R.A. has a contract with the Universitat de València under the Ramón y Cajal programme (Ministerio de Ciencia y Tecnología). 


\section{References}

Bambauer, A., Rainey, F. A., Stackebrandt, E. \& Winter, J. (1998). Characterization of Aquamicrobium defluvii gen. nov., sp. nov., a thiophene-2-carboxylate-metabolizing bacterium from activated sludge. Arch Microbiol 169, 293-302.

Biebl, H., Tindall, B. J., Pukall, R., Lunsdorf, H., Allgaier, M. \& Wagner-Dobler, I. (2006). Hoeflea phototrophica sp. nov., a novel marine aerobic alphaproteobacterium that forms bacteriochlorophyll a. Int J Syst Evol Microbiol 56, 821-826.

Cashion, P., Holder-Franklin, M. A., McCully, J. \& Franklin, M. (1977). A rapid method for the base ratio determination of bacterial DNA. Anal Biochem 81, 461-466.

Cavanaugh, C. M. (1994). Microbial symbiosis: patterns of diversity in the marine environment. Am Zool 34, 79-89.

De Ley, J., Cattoir, H. \& Reynaerts, A. (1970). The quantitative measurement of DNA hybridization from renaturation rates. Eur J Biochem 12, 133-142.

Fritsche, K., Auling, G., Andreesen, J. R. \& Lechner, U. (1999). Defluvibacter lusatiae gen. nov., sp. nov., a new chlorophenoldegrading member of the $\alpha-2$ subgroup of proteobacteria. Syst Appl Microbiol 22, 197-204.

Garrity, G. M., Bell, J. A. \& Lilburn, T. G. (2004). Taxonomic outline of the prokaryotes. In Bergey's Manual of Systematic Bacteriology, 2nd edn, release 5.0. http://dx.doi.org/10.1007/bergeysoutline200310

Gerhardt, P., Murray, R. G. E., Wood, W. A. \& Krieg, N. R. (editors) (1994). Methods for General and Molecular Bacteriology. Washington, DC: American Society for Microbiology.

Huß, V. A. R., Festl, H. \& Schleifer, K. H. (1983). Studies on the spectrophotometric determination of DNA hybridization from renaturation rates. Syst Appl Microbiol 4, 184-192.

Jagoueix, S., Bove, J.-M. \& Garnier, M. (1994). The phloemlimited bacterium of greening disease of citrus is a member of the $\alpha$ subdivision of the Proteobacteria. Int J Syst Bacteriol 44, 379-386.

Jarvis, B. D. W., Van Berkum, P., Chen, W. X., Nour, S. M., Fernandez, M. P., Cleyet-Marel, J. C. \& Gillis, M. (1997). Transfer of Rhizobium loti, Rhizobium huakuii, Rhizobium ciceri, Rhizobium mediterraneum, and Rhizobium tianshanense to Mesorhizobium gen. nov. Int J Syst Bacteriol 47, 895-898.

Kämpfer, P. \& Kroppenstedt, R. M. (1996). Numerical analysis of fatty acid patterns of coryneform bacteria and related taxa. Can J Microbiol 42, 989-1005.

Kämpfer, P., Müller, C., Mau, M., Neef, A., Auling, G., Busse, H. J., Osborn, A. M. \& Stolz, A. (1999). Description of Pseudaminobacter gen. nov. with two new species, Pseudaminobacter salicylatoxidans sp. nov. and Pseudaminobacter defluvii sp. nov. Int J Syst Bacteriol 49, 887-897.

Knösel, D. H. (1984). Genus IV. Phyllobacterium (ex Knösel 1962) nom. rev. (Phyllobacterium Knösel 1962, 96). In Bergey's Manual of Systematic Bacteriology, vol. 1, pp. 254-256. Edited by N. R. Krieg \& J. G. Holt. Baltimore: Williams \& Wilkins.

Labbé, N., Parent, S. \& Villemur, R. (2004). Nitratireductor aquibiodomus gen. nov., sp. nov., a novel $\alpha$-proteobacterium from the marine denitrification system of the Montreal Biodome (Canada). Int J Syst Evol Microbiol 54, 269-273.

Lane, D. J. (1991). 16S/23S rRNA sequencing. In Nucleic Acid Techniques in Bacterial Systematics, pp. 115-175. Edited by E. Stackebrandt \& M. Goodfellow. Chichester: Wiley.

Lewis, J., Kennaway, G., Franca, S. \& Alverca, E. (2001). Bacteriumdinoflagellate interactions: investigative microscopy of Alexandrium spp. (Gonyaulacales, Dinophyceae). Phycologia 40, 280-285.

Lilly, E. L., Halanych, K. M. \& Anderson, D. M. (2005). Phylogeny, biogeography, and species boundaries within the Alexandrium minutum group. Harmful Algae 4, 1004-1020.

Ludwig, W., Strunk, O., Klugbauer, S., Klugbauer, N., Weizenegger, M., Neumaier, J., Bachleitner, M. \& Schleifer, K.-H. (1998). Bacterial phylogeny based on comparative sequence analysis. Electrophoresis 19, 554-568.

Ludwig, W., Strunk, O., Westram, R. \& 29 other authors (2004). ARB: a software environment for sequence data. Nucleic Acids Res 32, 1363-1371.

Mesbah, M., Premachandran, U. \& Whitman, W. B. (1989). Precise measurement of the $\mathrm{G}+\mathrm{C}$ content of deoxyribonucleic acid by high-performance liquid chromatography. Int J Syst Bacteriol 39, 159-167.

Moore, E. R. B., Arnscheidt, A., Krüger, A., Strömpl, C. \& Mau, M. (1999). Simplified protocols for the preparation of genomic DNA from bacterial cultures. In Molecular Microbial Ecology Manual, pp. 1.6.1.1-1.6.1.15. Edited by A. D. L. Akkermans, J. D. van Elsas \& F. J. de Bruijn. Dordrecht: Kluwer Academic.

Oppenheimer, C. H. \& ZoBell, C. E. (1952). The growth and viability of sixty-three species of marine bacteria as influenced by hydrostatic pressure. J Mar Res 11, 10-18.

Orphan, V. J., Hinrichs, K. U., Ussler, W., III, Paull, C. K., Taylor, L. T., Sylva, S. P., Hayes, J. M. \& DeLong, E. F. (2001). Comparative analysis of methane-oxidizing archaea and sulfate-reducing bacteria in anoxic marine sediments. Appl Environ Microbiol 67, 1922-1934.

Peix, A., Rivas, R., Trujillo, M. E., Vancanneyt, M., Velázquez, E. \& Willems, A. (2005). Reclassification of Agrobacterium ferrugineum LMG 128 as Hoeflea marina gen. nov., sp. nov. Int J Syst Evol Microbiol 55, 1163-1166.

Schleheck, D., Tindall, B. J., Rosselló-Mora, R. \& Cook, A. M. (2004). Parvibaculum lavamentivorans gen. nov., sp. nov., a novel heterotroph that initiates catabolism of linear alkylbenzenesulfonate. Int J Syst Evol Microbiol 54, 1489-1497.

Stackebrandt, E. \& Goebel, B. M. (1994). Taxonomic note: a place for DNA-DNA reassociation and 16S rRNA sequence analysis in the present species definition in bacteriology. Int J Syst Bacteriol 44, 846-849.

Urakami, T., Araki, H., Oyanagi, H., Suzuki, K. \& Komagata, K. (1992). Transfer of Pseudomonas aminovorans (den Dooren de Jong 1926) to Aminobacter gen. nov. as Aminobacter aminovorans comb. nov. and description of Aminobacter aganoensis sp. nov. and Aminobacter niigataensis sp. nov. Int J Syst Bacteriol 42, 84-92. 